\title{
Catalyst Twenty-Twenty: Post-Traumatic Growth at Scales of Person, Place and Planet
}

\author{
Alan C. Logan ${ }^{1}$, Susan H. Berman 1,2, Richard B. Scott ${ }^{1,2}$, Brian M. Berman ${ }^{1,2,3}$ and Susan L. Prescott ${ }^{1,2,4, *}$ \\ 1 inVIVO Planetary Health, the Worldwide Universities Network (WUN), Baltimore, MD 21231, USA; \\ alanxlogan@gmail.com (A.C.L.); sberman@tiih.org (S.H.B.); rscott@tiih.org (R.B.S.); \\ bberman@tiih.org (B.M.B.) \\ 2 The Institute for Integrative Health, Baltimore, 1407 Fleet St, Baltimore, MD 21231, USA \\ 3 Center for Integrative Medicine, Department of Family and Community Medicine, University of Maryland \\ School of Medicine, Baltimore, MD 21201, USA \\ 4 The ORIGINS Project, Telethon Kids Institute, University of Western Australia, Perth Children's Hospital, \\ 15 Hospital Avenue, Nedlands, WA 6009, Australia \\ * Correspondence: Susan.Prescott@telethonkids.org.au
}

Citation: Logan, A.C.; Berman, S.H.; Scott, R.B.; Berman, B.M.; Prescott, S.L. Catalyst Twenty-Twenty: Post-Traumatic Growth at Scales of Person, Place and Planet. Challenges 2021, 12, 9. https://doi.org/ $10.3390 /$ challe12010009

Academic Editor: Palmiro Poltronieri

Received: 12 February 2021

Accepted: 9 March 2021

Published: 13 March 2021

Publisher's Note: MDPI stays neutral with regard to jurisdictional claims in published maps and institutional affiliations.

Copyright: (c) 2021 by the authors. Licensee MDPI, Basel, Switzerland. This article is an open access article distributed under the terms and conditions of the Creative Commons Attribution (CC BY) license (https:/ / creativecommons.org/licenses/by/ $4.0 /)$.

\begin{abstract}
Planetary health is a broad multidisciplinary effort that attempts to address what has been described as "Anthropocene Syndrome" - the wicked, interrelated challenges of our time. These include, but are not limited to, grotesque biodiversity losses, climate change, environmental degradation, resource depletion, the global burden of non-communicable diseases (NCDs), health inequalities, social injustices, erosion of wisdom and civility, together with the many structural underpinnings of these grand challenges. The ultimate aim of planetary health is flourishing along every link in the person, place and planet continuum. The events of "2020" have illuminated the consequences of "mass trauma" and how sub-threshold anxiety and/or depressive symptoms erase the rigid lines between mental "health" and mental "disorders", and unmasked the systemic forms of injustice, discrimination, and oppression that have too often escaped discourse. Here, we query the ways in which post-traumatic growth research might inform the larger planetary health community, especially in the context of a global pandemic, broadening socioeconomic inequalities, a worsening climate crisis, and the rise of political authoritarianism. The available research would suggest that "2020" fulfills the trauma criteria of having a "seismic impact on the assumptive world", and as such, provides fertile ground for post-traumatic growth. Among the many potential positive changes that might occur in response to trauma, we focus on the value of new awareness, perspective and greater wisdom.
\end{abstract}

Keywords: post-traumatic growth; planetary health; wisdom; self-distancing; awareness; mindfulness; COVID-19; non-communicable diseases (NCDs); biodiversity losses; climate change; environmental degradation; flourishing; positive contagion; mental health

\section{Introduction}

"With my barn burned down, nothing obstructs my view of the moon overhead" Mizuta Masahide, Japanese poet (1657-1723).

The quote above is oft-used in the growing body of literature within the field of post-traumatic growth - despite his storehouse being destroyed by fire, Masahide was able to see things from a new perspective, and identify at least one source of awe and wonder that was previously concealed from view. Masahide's ability to process a traumatic event, in a way that might ultimately (over time) lead to positive change, is at the heart of contemporary post-traumatic growth research. In particular, post-traumatic growth is characterized perceived positive change in the areas of personal strength, appreciation of life, interpersonal functioning, spiritual change, and greater awareness of new possibilities in life. 
Here, in our Viewpoint paper, we query the ways in which post-traumatic growth research might inform the larger planetary health community, especially in the context of a global pandemic, broadening socioeconomic inequalities, a worsening climate crisis, and the rise of political authoritarianism. The events of " 2020 " have erased the rigid lines between mental health and mental disorder, illuminating the consequences of subthreshold (anxiety and/or depressive) symptoms, "mass trauma" and systemic forms of injustice, discrimination, and oppression that have too often escaped discourse [1-3]. While experts warn that a mental health crisis is looming ahead—and that message should be taken seriously [4] - there are also signs that the seismic events of 2020 are acting as a catalyst, increasing awareness of an unhealthy status quo. The COVID-19 crisis has unmasked long-standing structural disadvantage and various barriers to health that were previously "hidden" in plain sight [5].

At the outset, we underscore that, in the medical and scientific literature, "2020" has become shorthand for "a year to remember" [6-10] (Figure 1). Obviously, the direct pathological threat of the SARS-CoV-2 virus is central to the 2020 moniker, but it was also a year that witnessed numerous (oft-related) seismic events-global protests against racial injustice [11], crisis-level spread of dis/misinformation [12], the rise of political authoritarianism [13], unprecedented wildfires in Australia [14], further reports that US life expectancy is declining (after decades of gain) [15,16], and massive wealth accumulation among a sliver of the global population [17] while precariousness and food and housing insecurity increased [18-20]. At the individual level, seismic events can promote growth. It is our contention that the mass trauma associated with 2020 might also allow for large scale post-traumatic growth, a re-appraisal of values, awareness of new possibilities, and increased wisdom (Figure 2) - to "see the Moon overhead" and rebuild a better, more sustainable barn.

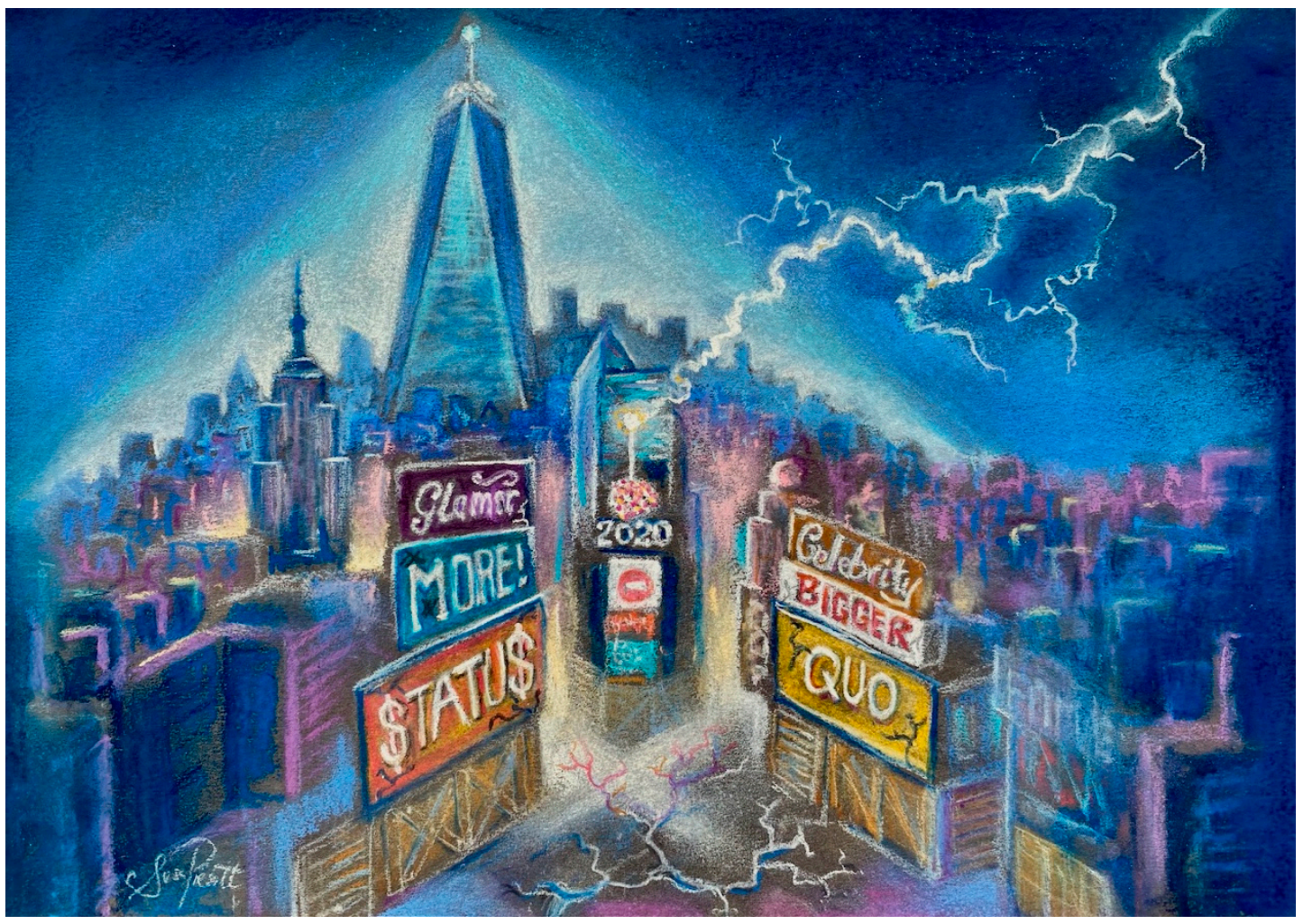

Figure 1. A year to remember: 2020 has been a year of numerous seismic events, spanning from the COVID-19 pandemic, global protests against racial injustice, crisis-level spread of dis/misinformation, the rise of political authoritarianism, catastrophic environmental events, growing disparities in health and life expectancy, and massive wealth accumulation among the privileged as food and housing insecurity increased further among the disadvantaged. (Artwork by S.L.P.). 


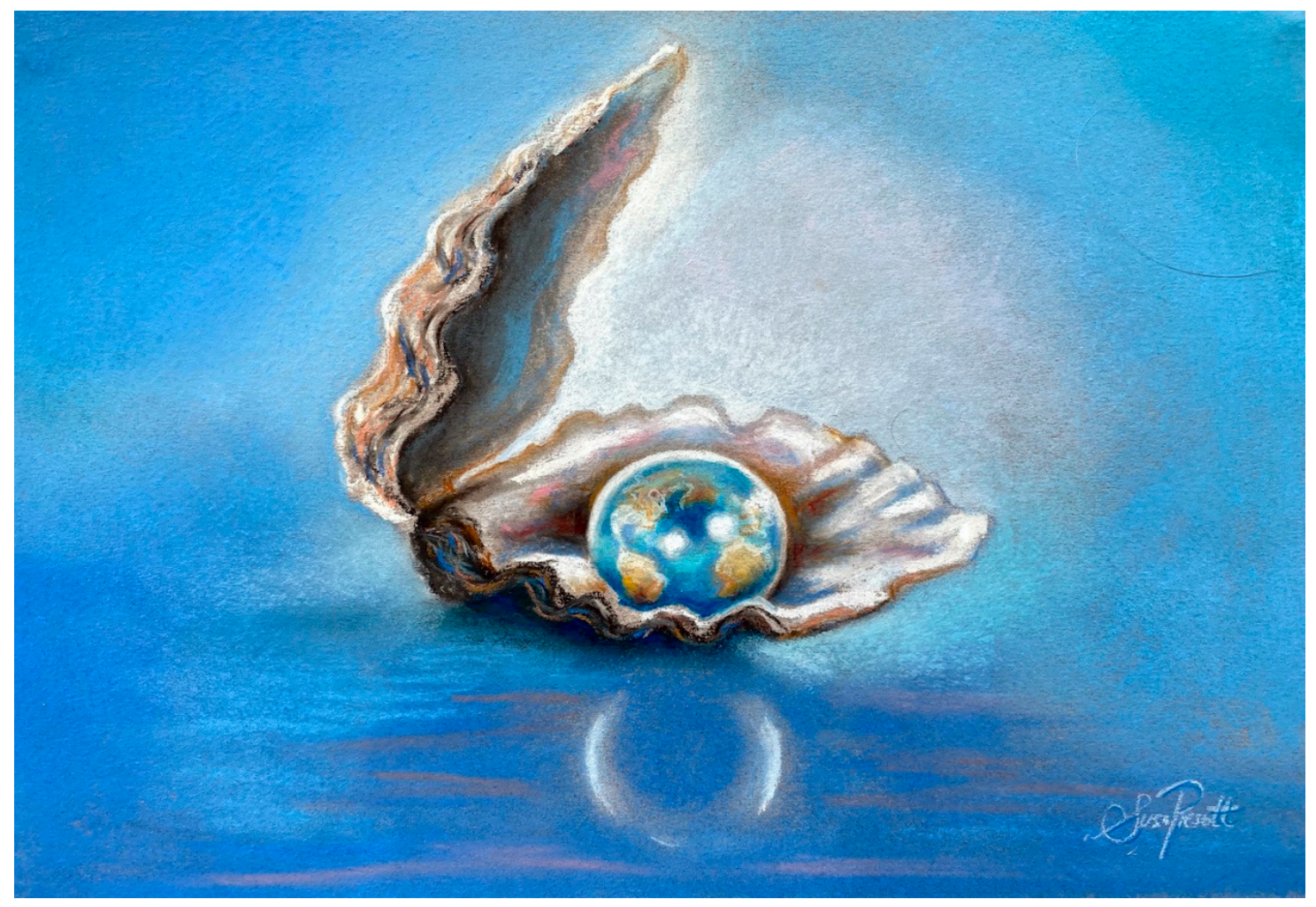

Figure 2. Post Traumatic Growth: The well-recognized positive responses to trauma range from new awareness, wisdom, meaning, purpose and greater appreciation of life. The aftermath of the "mass trauma" associated with 2020, may therefore allow opportunities for large scale post-traumatic growth, a re-appraisal of values, higher levels of environmental and social concern, awareness of new possibilities, and greater shared wisdom. (Artwork by S.L.P.).

\section{Post-Traumatic Growth}

"The very greatest things - great thoughts, discoveries, inventions - have generally been nurtured in hardship, often pondered over in sorrow... if there were nothing to struggle for, there would be nothing to be achieved" Editors of The Friend magazine, 1866 [21].

Throughout history and across cultures, humans have held onto the idea that trauma and adversity can lead to positive change. In particular, this notion has been embedded in religious and philosophical writings, as well as ancient mythology. It was not until the 1990s, with the validation of the Post-Traumatic Growth Inventory [22], that a cohesive area of psychological study began to examine the concept of post-traumatic growth. In line with the word "struggle" in the quote above, the term post-traumatic growth refers to "positive psychological change experienced as a result of the struggle with highly challenging life circumstances" [23].

Post-traumatic growth (henceforth, PTG) research does not minimize the potentially devastating and far-reaching negative effects of trauma-volumes of research demonstrate the long-term health consequences of acute and chronic trauma exposure [24-27]. Indeed, the available research shows that PTG coexists with ongoing distress [28], and although there is evidence of benefit to health and wellbeing (discussed below) [29], PTG is not a curative of trauma symptoms. Rather, PTG research examines the ways in which traumatic events become a catalyst for growth, learning and re-evaluation of worldviews. PTG research extends beyond catastrophic life events (e.g., combat experiences, violent assault, direct witness to horrifying events) that have been at the historical core of posttraumatic stress disorder (PTSD) research. In the context of PTG research, the words trauma, major crisis, and highly stressful events are used interchangeably, with the common thread being an event(s) acting as a major challenge to individuals - especially if it challenges the way in which they understood/understand the world and their place in it [23]. As such, and 
because traumatic events often challenge communities and vast populations, PTG research has broad societal implications. In the context of PTG, trauma is certainly a subjective term, one that may or may not be associated with the marked physiological changes that are often noted in PTSD; what constitutes 'traumatic' in PTG discourse can be a product of culture and may change over time, but it best described by what it is not-the 'daily hassles' and minor stressors that, although not without negative health consequences, are a common feature of modern life [30].

While PTG discourse has oft-overlapped with the concept of resiliency (and "hardiness"), optimism and pre-trauma assets/abilities to withstand trauma, it is important to note that PTG research attempts to understand the "processes people use as they struggle with the aftermath of trauma to derive meaning, feel wiser, and face uncertain futures with more confidence" [22] (Figure 3). Hence, PTG research emphasizes both the processes and the outcomes associated with growth. At the same time, PTG cannot be uncoupled from personality features, available resources, and the larger cultural narratives that surround an individual or community over time [31,32]. For example, higher social support, spirituality, optimism, active coping strategies, and purpose in life may predict subsequent PTG over time [33-35]. Since optimism and social support networks can be assets of affluence [36-39], PTG cannot be uncoupled from complex "exposome" discussions-that is, the total accumulated environmental exposures (both detrimental and beneficial) that help us understand the response of humans to the total environment over time [40].

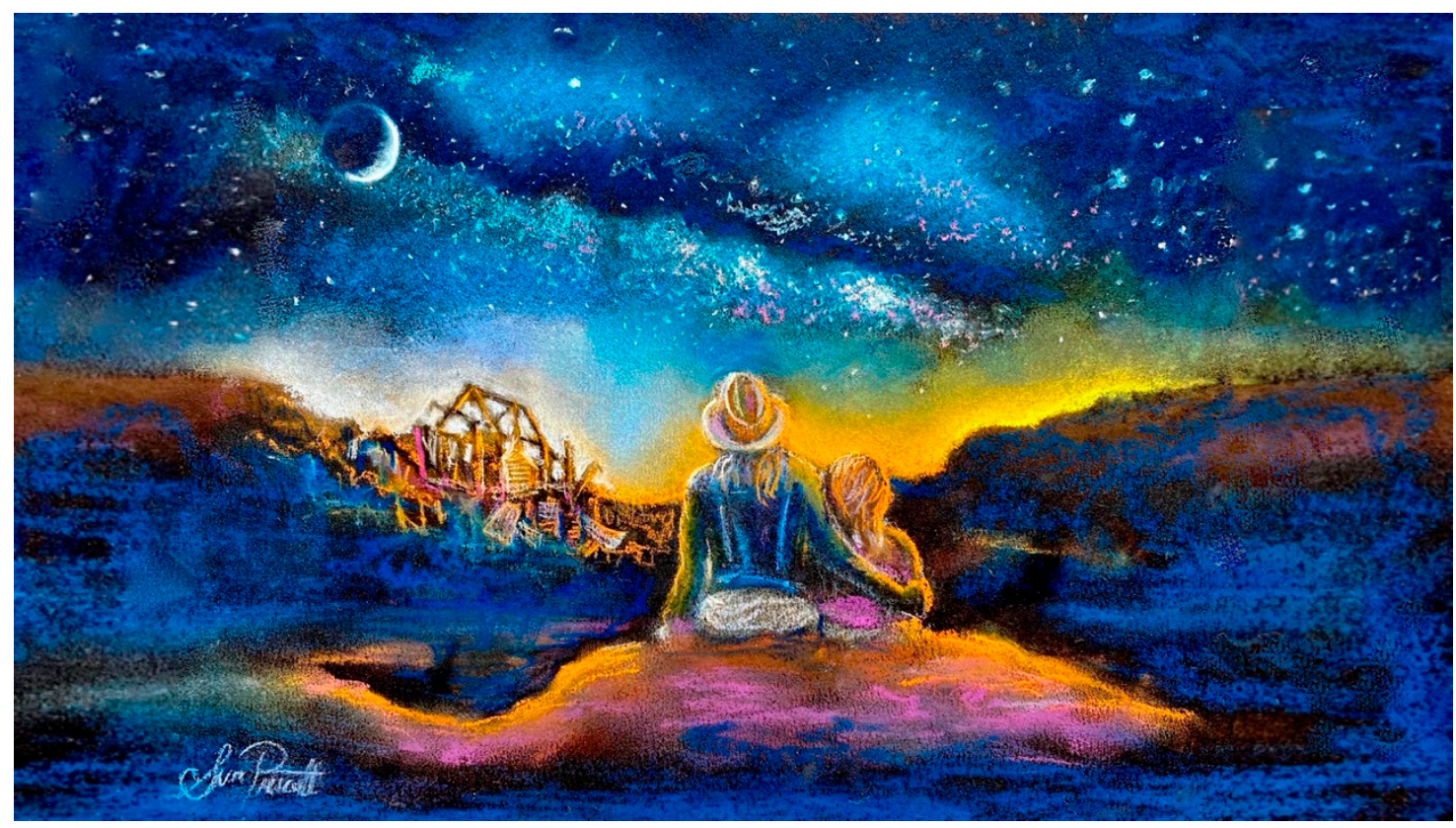

Figure 3. Traumatic events can act as catalysts that accelerate change through new awareness and new opportunities that might not have occurred (or taken longer). (Image inspired by wisdom of Japanese poet Mizuta Masahide; created by S.L.P).

The broad interpretation of the word "trauma" and reliance upon cross-sectional studies with retrospective data collection has been a major limitation within the field of PTG. The extent to which individuals experience PTG and maintain such growth in a way that promotes wellbeing and/or physical health over time remains far from clear [41]. Still, a recent meta-analysis indicates that approximately half of individuals who experienced traumatic events report moderate-to-high levels of PTG [42]. Whether or not perceived (vs. actual) PTG is part of a coping process (that is, the "psychological immune system", cognitive mechanisms that maintain a sense of well-being during times of adversity and distress [43]) is a matter of ongoing research [44]; it is not our contention that PTG is a scientific field wherein all the answers can be found. Rather, we suggest that salient 
portions of the available PTG research might inform the larger networks of planetary health (Figure 4).

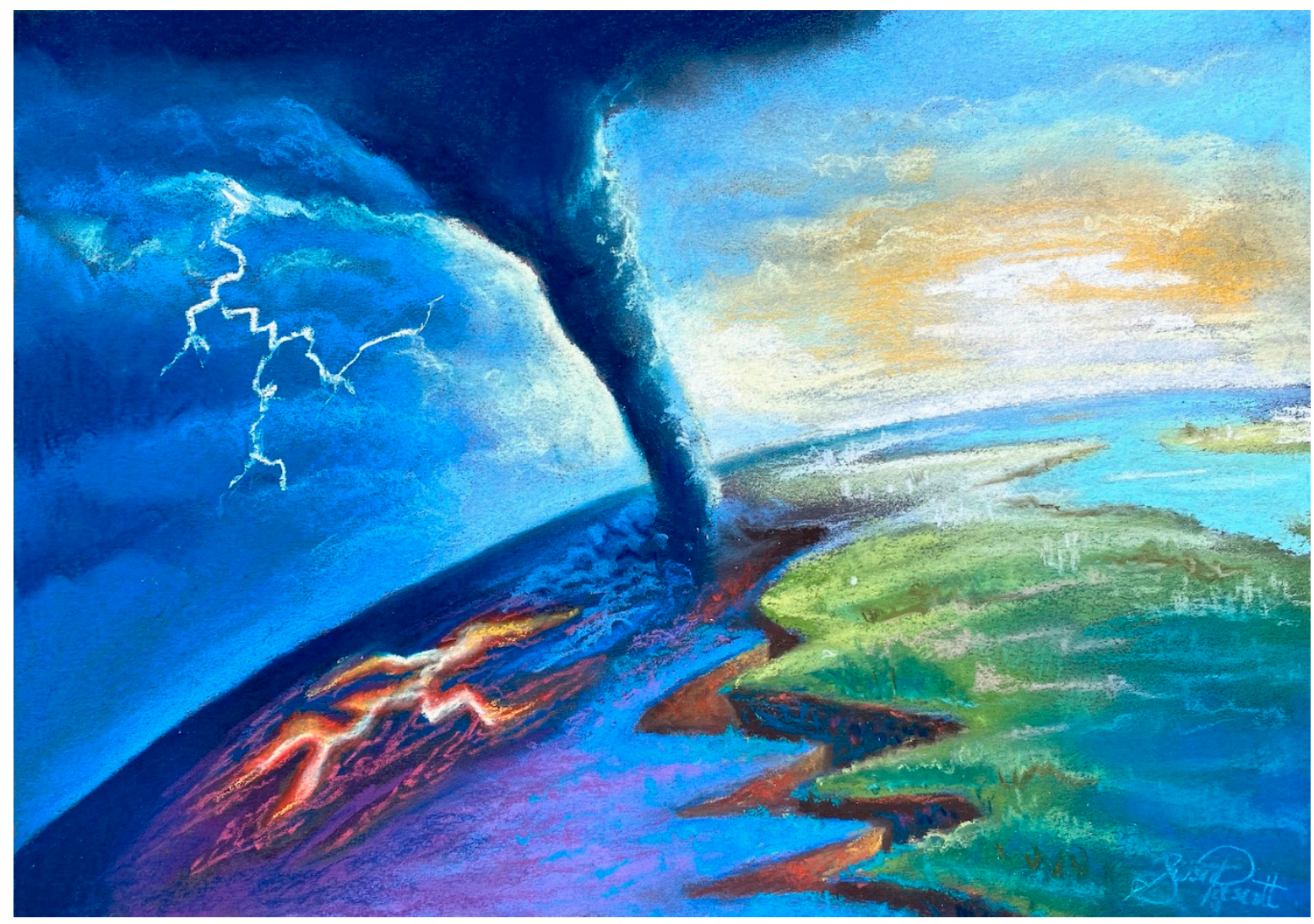

Figure 4. Challenges that break the status quo can provide new or accelerated opportunities for change. Acute events can unmask chronic problems that seemed impossible to overcome or may not have even been recognized. The new perspectives and greater awareness that result can create new possibilities and galvanize action. What applies to personal growth may apply equally at collective scales. (Artwork by S.L.P.).

\section{New Awareness and Wisdom}

"I want those who follow us to look back on us as wise ancestors, good ancestors" Jonas Salk. 1984 [45].

Among the many potential positive changes that might occur in response to trauma, new awareness and increased wisdom are central to the growth concept. The new awareness ranges from increased awareness of human potential, existential awareness (meaning and purpose) and greater appreciation of life [46-48]. The validated Posttraumatic Growth Inventory (PTGI) includes "New Possibilities" questions such as "New opportunities are available, which wouldn't have been otherwise" and "I established a new path for my life".

While meaning and purpose in life are often considered to be synonymous, the distinction is worth noting; experts have concluded that 'lives may be experienced as meaningful when they are felt to have significance beyond the trivial or momentary, to have purpose, or to have a coherence that transcends chaos [49]. Thus, meaning in life has three primary facets-a life with (i) value and significance, (ii) a broader purpose, and (iii) coherence as part of a comprehensible whole [50]. Among these facets, purpose in life has been the subject of robust research. Generally, a high degree of purpose in life is associated with goals, big picture thinking, and a long view [51]. Higher levels of purpose in life predicts healthy behaviors [52,53], lower allostatic load (physiological "wear and tear" due to chronic stress) [54] and lower non-communicable disease risk [55,56]. Among combat veterans with PTSD, lower purpose in life scores are a significant predictor of 
suicidal ideation over time [57]. Since the adoption of healthy lifestyle habits also increase self-reported purpose in life, the overall wellbeing benefits may accrue in a bidirectional manner [58].

In research settings, wisdom is defined as "morally-grounded excellence in socialcognitive processing". Here, moral grounding refers to a set of inter-related aspirational goals: balance of self, pursuit of truth (vs. dishonesty), and pro-social orientation toward shared humanity. Excellence in social-cognitive processing refers to the application of certain forms of meta-cognition to reasoning and problem-solving in situational domains that have the potential to affect other people. This includes intellectual humility (awareness of one's limited knowledge), context-adaptability (pragmatic reasoning, open-mindedness to change), perspectivism (considering different perspectives and long-term thinking), dialectical/reflective thinking (balancing and integration of viewpoints, including opposing perspectives), and epistemic/intellectual humility (e.g., unbiased/accurate thinking, seeing through illusions, understanding one's limitations) [59]. Validated instruments such as the Self-Assessed Wisdom Scale, the Three-Dimensional Wisdom Scale, and the Brief Wisdom Screening Scale, can capture many of the aforementioned aspects of wisdom, as well as humor and emotional regulation which are also seen as critical components of wisdom [60]. Like purpose in life, wisdom has also been linked with post-traumatic growth, enhanced mental health outcomes, subjective wellbeing and quality of life [61-63]. Wisdom is specifically associated with a type of self-reflection (when recalling difficult life experiences) that engages explanatory processing - extracting lessons, insights and meaning [64]. Indeed, post-traumatic increases in wisdom may further facilitate healthassociated variables such as forgiveness, gratitude and spirituality [65].

It is important to note that the experience of PTG does not automatically equate to wisdom. As stated by experts in the field, "it is inaccurate to assume that all people who report PTG are also wiser. The degree to which this may be true would depend on the particular definition of wisdom and the particular type of PTG" [66]. Of course, the academic concept of wisdom is oft-confined to a westernized perspective [67,68]; although the concept of trauma differs across cultures, PTG has been observed among diverse cultural groups, with the available research indicating that PTG is a universal experience [66]. More work is needed to tie together non-western conceptions of wisdom and PTG.

\section{Post Twenty-Twenty}

"Posttraumatic growth is not simply a return to baseline" Richard Tedeschi, Lawrence Calhoun. 2004.

Thus far, we have outlined some of the salient components of the burgeoning PTG research. Now, we turn our attention to the ways in which aspects of PTG-most notably new awareness and wisdom at the individual level—might be elevated on larger scales, from place (community) to planet. Already, international researchers have reported COVID19 related PTG among individuals_-including the embracing of new possibilities, openness to the future, positive spiritual change, greater appreciation of life, identification with larger humanity, and improved relationships [69-71]. In the context of "2020", this preliminary research provokes a critical question: how can we "boost" wisdom?

Among the various wisdom-enhancing techniques used by educators, "self-distancing" is emerging as one of the most effective strategies; this involves adopting a "detached" or ego-decentered viewpoint while reflecting on past (or imagined future) experiences of adversity. This process is often described as a "fly on the wall" perspective, with the reflection using third person language (as opposed to first person, self-immersed reflection). Self-distancing leads to lower levels of negative affect and physiological reactivity after reflecting on past events, and reduces emotional reactivity about future stressors [72,73]. In the context of PTG, people who reflect on everyday adversity from a self-distanced perspective experienced growth in their positive emotionality [74], and several experimental studies indicate that self-distancing can promote wise reasoning [75-78]. Experiments 
demonstrate that cueing people to reason about personally meaningful issues (e.g., Career prospects for the unemployed during an economic recession; and anticipated societal changes associated with one's chosen candidate losing the 2008 U.S. Presidential election) from a distanced perspective enhances wise reasoning (dialecticism; intellectual humility), attitudes (cooperation-related attitude assimilation), and behavior (willingness to join a bipartisan group) [76]. While more research is required on the utility of self-distancing in the context of " 2020 " trauma, such findings suggest that the techniques may have value in addressing large-scale, complex, interrelated trauma.

The detachment principle of self-distancing is also a central component of mindfulness [79]; thus it is unsurprising that mindfulness exercises are also an important part of teaching interventions that have been shown to promote PTG [80] and wisdom [81,82].

As mentioned earlier, many scholars emphasize the role of emotions in wise behaviors. As argued by Professor Judith Gluck (see Wisdom, Box 1), who has studied wisdom for over twenty years, seeing through illusion and self-deception along the path to wise reasoning requires emotional awareness, emotion regulation, and empathy [83]. Since moral grounding is the fulcrum of wisdom, experts have focused in on the emotions that might underpin the moral grounding of wisdom, including the "self-transcendent" emotions of compassion, gratitude and awe [84]. As self-transcendent emotions are oriented toward lifting up the wellbeing of others, they offer a tantalizing pathway toward the wisdom required for post-2020 growth. Indeed, scholars Dacher Keltner and Paul Piff have made a strong case for awe, already well-known for its ability to amplify humility, scientific reasoning and pro-social attitudes and behaviors, as the emotion that morally grounds wisdom [85] (see Awe, Box 2).

Box 1. The Wisdom Mindset.

Dr. Judith Gluck and colleagues (2019) state that wisdom is "deep, personal, experience-based knowledge about life that is acquired through and goes along with a certain mindset". The hallmark of that mindset is "the willingness and ability to take a broad, non-self-centered perspective on life with the goal of understanding it in all its complexity; [individuals with] this mindset are more likely than others to learn more about life and accumulate wisdom-related knowledge over time, and they are more often able to deal with difficult situations wisely". Dr. Gluck and colleagues conclude by emphasizing that a greater understanding of how we can foster the wisdom mindset "may be one of the most crucial questions for humanity at this point" [78].

Box 2. The Power of Awe.

Awe is a positive emotion that is typically provoked by grand stimuli (e.g., viewing scenes of the Earth from space, vast scenes of breathtaking nature, or childbirth can provoke awe); aweprovoking stimuli often present with an element of mystery and wonder; a scene or event that is not immediately understood [86,87]-perhaps indistinct with what philosophers refer to as the sublime [88]. Awe has been connected to lower systemic inflammation, emotional wellbeing, increased life satisfaction, mindfulness, increased patience, decreased materialism, and pro-social and pro-environmental behaviors [89-92]. Awe enhances openness to learning, the desire to innovate and engage in creative pursuits [89]. While studies have generally examined short-term outcomes after awe induction, it has been argued that awe is much more than a 'fleeting moment' emotion; rather, it has steady-state properties with much larger, transformative implications to health and vitality at scales of person, place and planet [93]. As stated by expert Kirk Schneider: "To the extent that people are deficient in awe for life, they are much more prone to be embittered, to feel desolate or numb and to protect their hunger for spiritual connection on quick fixes, whether they be commercial products or leaders or mass movements" [94].

Preliminary research from China has shown that the magnitude of the COVID-19 pandemic is associated with awe; while vast experiences such as natural disasters can induce "negative" awe, associated with threat (anxiety, fear), and the pandemic appears no different in that regard, researchers have found positive awe associated with COVID-19, including stronger feelings of admiration, inspiration, and optimism. Researchers, in their 
examination of green consumption behaviors, concluded that the positive awe of COVID19 stems from the greatness of life, the selfless acts of healthcare heroes, and the collective heroism displayed by volunteers. Moreover, individuals with pandemic-associated positive awe had higher levels of environmental and social concern, and that this environmental concern significantly increased (experimental) green consumption behavior [95].

\section{Growth from One, to Many}

"Everything can be taken [except] one thing: the last of the human freedoms-to choose one's attitude in any given set of circumstances, to choose one's own way," Viktor E. Frankl, 1959 [96].

As mentioned, the bulk of PTG research pertains to the experience of individuals. At present, we cannot assume that responses to trauma at the individual level, and the experience of PTG, can be neatly multiplied from person to the group level, and ultimately, to the global level. To do so would ignore the diverse total lived experiences of individuals and groups, and the disparate group level ecology (institutions, environment, public health, etc.) that shape the lived experiences from micro, meso and to macro scales. Individual and cultural differences will be at play. For example, recent research from Greece indicates that the relatively stable trait of dispositional optimism is a key driver of COVID-related PTG. Specifically, dispositional optimism predicts the ability of individuals to draw personal strength and explore new perspectives in the context of COVID-19 associated PTG [97]. While individual level optimism can be malleable and increased through interventions [98], it is important to note that higher levels of optimism and/or lower levels of pessimism (the absence of pessimism is a health variable distinct from the presence of optimism [99]) are linked to socioeconomic advantage [100,101]. On the other hand, overly optimistic outlooks can impede realistic expectations about the future, maintain an unhealthy status quo, and subsequently act as a barrier to health promotion [102] and it can also imply that those who do not take a positive attitude toward disaster are at personal fault. Thus, our contention that "Twenty-Twenty"-associated PTG might spread across networks and nations is perhaps, itself, overly optimistic, and is certainly predicated on individual and cultural differences, including pre/post COVID conditions that might either facilitate or hinder PTG.

With that major caveat in place, we can point out that there is some evidence that PTG is "transmissible" to close others, and even to larger groups and social systems [66,103]. For example, life partners, siblings and/or caregivers of cancer patients or cancer survivors have reported PTG in various studies [104-107]. Related to this research is so-called vicarious (or secondary) PTG wherein first responders, healthcare workers and/or those who spend extended time with trauma survivors, experience PTG [108-111]. Research drawn from military, first responder and healthcare professions (where the likelihood of direct and vicarious exposure to trauma is common) has resulted in organizational responses that might facilitate PTG [112]. The potential for pandemic-related PTG at the organizational level has already been put forth by leaders in the field of PTSD; citing examples such as the post-Hurricane Katrina transformation of the New Orleans healthcare system, experts contend that there is an opportunity to establish a "new normal" in which organizations are not only restored, but achieve a higher level of functioning as a result of addressing and learning from a traumatic event [113]. Trauma can certainly impact organizations (e.g., natural disasters, homicide, suicide, fire, massive financial crime, harassment, discrimination) and, much like individual-level PTG, the pre-trauma assets of organizations (e.g., a culture of empathy, compassion, support, wisdom) may determine the extent to which PTG may occur [112]; at this point researchers are only beginning to examine the 'collective cognitions', especially by leadership, that might provoke workplace or organizational PTG [114,115].

Recall, it is not a specific trauma per se that causes growth; rather, it is the struggle and response to the trauma. History is replete with examples of mass trauma (natural and human-made catastrophes) leading to the sharing and integration of individual narratives 
into a large-scale whole [116,117]. In recent years, the survivors of school shootings (and their parents) in the United States have galvanized a movement, one with a clear sense of purpose in the efforts toward meaningful, long-overdue policy changes [118,119]. At the same time, the experiences of mass trauma uncovers preexisting inequalities and injustice; this has certainly been the case with COVID-19, where the heaviest burden is shouldered by disadvantaged individuals and communities [120]; disparate responses by government and organizations to COVID-19 (some ignoring expert public health guidance), and the ability of certain advantaged individuals (often with occupations easily operable via online services) has challenged the notion that "we are all in this together" [121]. Still, even though the events of "Twenty-Twenty" have not evoked equal levels of trauma throughout communities and across borders, and many of the Anthropocene's unhealthy status quo hallmarks (and its attendant misinformation mess [12]) seem as entrenched as ever, the available PTG research has a place in the discourse of health at scales of person, place and planet.

While individual PTG is associated with an examination of who the person "is" in the aftermath of trauma, mass trauma can provoke examination of who "we" are, and what meaning can be drawn from the trauma. Research shows that traumatic experiences can enable growth in individuals' leadership capacity [112], which supports the many historical examples wherein seismic trauma leads to the emergence of previously unknown citizens who take morally grounded leadership roles [23,122]. Although times of great fear have provided a Petri dish for enhanced "in-group" affiliation and the rise of political authoritarianism, the emergence of wise citizens and leaders can provide an antidote [123]; given the human propensity to mimic the behavior of others [124], elevating the narratives of moral exemplars - individuals who have lived their lives in a morally exceptional manner-may be an important part of the path to promote post-2020 wisdom [125].

\section{Conclusions}

"We have a duty to trumpet the reality of post-traumatic growth, not only to those who have experienced PTSD or are likely to, but to society as a whole, so that when tragedy does strike we are prepared to receive its victims with a supportive and knowledgeable embrace; informed by science, warmed by compassion" Samuel Dickinson, Weill Cornell Medical College. 2020 [126].

In the aftermath of "2020", it can be easy to forget that the pre-pandemic world was already facing wicked, interrelated challenges known as 'Anthropocene Syndrome' [127]. There was already a mental health crisis, environmental calamities and unprecedented levels of NCDs. In the wake of "2020", much has been written on the large-scale mental health implications of the global pandemic, and rightfully so. Yet, the ever-increasing body of research under the rubric of PTG may also provide salient, and certainly hopeful, information.

While the general public is very familiar with the term post-traumatic stress disorder, a much smaller fraction are aware of PTG [128]. Perhaps "2020" provides an opportunity to raise awareness of PTG, and emphasize its components, such as new possibilities, selfdistancing, mindfulness and wisdom. Obviously, there are untold numbers of unanswered research questions, yet the available research would suggest that " 2020 " fulfills the trauma criteria of having a "seismic impact on the assumptive world", and as such, provides fertile ground for PTG, and associated wise reasoning.

Author Contributions: Conceptualization, data curation, original draft preparation, A.C.L. and S.L.P.; review editing and project administration, S.H.B., R.B.S. and B.M.B. Art creations by S.L.P. All authors have read and agreed to the published version of the manuscript.

Funding: This work received no external funding.

Institutional Review Board Statement: Not applicable.

Informed Consent Statement: Not applicable.

Data Availability Statement: Not applicable. 
Conflicts of Interest: A.C.L. is the author of trade book "The Greatest Hoax on Earth: Catching Truth While We Can" (ISBN 9781736197400) published in 2020 on aspects of the media, propaganda and post-truth. S.H.B., R.B.D., B.M.B. and S.L.P. declare no conflict of interest.

\section{References}

1. Horesh, D.; Brown, A.D. Traumatic Stress in the Age of COVID-19: A Call to Close Critical Gaps and Adapt to New Realities. Psychol. Trauma-Us 2020, 12, 331-335. [CrossRef] [PubMed]

2. Zhang, J.; Yang, Z.; Wang, X.; Li, J.; Dong, L.L.; Wang, F.S.; Li, Y.F.; Wei, R.H.; Zhang, J.P. The relationship between resilience, anxiety and depression among patients with mild symptoms of COVID-19 in China: A cross-sectional study. J. Clin. Nurs. 2020, 29, 4020-4029. [CrossRef]

3. Fernandez Turienzo, C.; Newburn, M.; Agyepong, A.; Buabeng, R.; Dignam, A.; Abe, C.; Bedward, L.; Rayment-Jones, H.; Silverio, S.A.; Easter, A.; et al. Addressing inequities in maternal health among women living in communities of social disadvantage and ethnic diversity. BMC Public Health 2021, 21, 176. [CrossRef]

4. Le, K.; Nguyen, M. The psychological burden of the COVID-19 pandemic severity. Econ. Hum. Biol 2021, 41, 100979. [CrossRef]

5. Team, V.; Manderson, L. How COVID-19 Reveals Structures of Vulnerability. Med. Anthropol. 2020, 39, 671-674. [CrossRef] [PubMed]

6. Poppas, A. 2020: A Year to Remember-And From Which to Learn. J. Am. Coll Cardiol 2021, 77, 659-660. [CrossRef] [PubMed]

7. Eisner, D.A. 2020: An unusual year. J. Gen. Physiol. 2021, 153, 2. [CrossRef] [PubMed]

8. Franklin, C. 2020-A year of changes, challenges and opportunities. J. Exp. Biol. 2021, 224 (Pt 1), jeb242155. [CrossRef]

9. Roberts, D.J. 2020: A year we will remember. Transfus Med. 2020, 30, 416-417. [CrossRef] [PubMed]

10. Nauleau, P.; Ralph, H. 2020: A year to remember. EBioMedicine 2021, 63, 103185. [CrossRef] [PubMed]

11. Cipriano, P.F.; Boston-Leary, K.; McMillan, K.; Peterson, C. The US COVID-19 crises: Facts, science and solidarity. Int. Nurs. Rev. 2020, 67, 437-444. [CrossRef]

12. Logan, A.C.; Berman, S.H.; Berman, B.M.; Prescott, S.L. Healing Anthropocene Syndrome: Planetary Health Requires Remediation of the Toxic Post-Truth Environment. Challenges 2021, 12, 1. [CrossRef]

13. Morabia, A. The Fascist Threat. Am. J. Public Health 2021, e1-e2. [CrossRef]

14. Zhang, Y.; Beggs, P.J.; McGushin, A.; Bambrick, H.; Trueck, S.; Hanigan, I.C.; Morgan, G.G.; Berry, H.L.; Linnenluecke, M.K.; Johnston, F.H.; et al. The 2020 special report of the MJA-Lancet Countdown on health and climate change: Lessons learnt from Australia's "Black Summer". Med. J. Aust. 2020, 213, 490-492. [CrossRef] [PubMed]

15. Mehta, N.K.; Abrams, L.R.; Myrskyla, M. US life expectancy stalls due to cardiovascular disease, not drug deaths. Proc. Natl. Acad. Sci. USA 2020, 117, 6998-7000. [CrossRef]

16. Harper, S.; Riddell, C.A.; King, N.B. Declining Life Expectancy in the United States: Missing the Trees for the Forest. Annu. Rev. Public Health 2020, 42, 2021.

17. Collins, C. Updates: Billionaire Wealth, US Job Losses and Pandemic Profiteers. Inequality.Org. 26 January 2021. Available online: https:/ / inequality.org/great-divide/updates-billionaire-pandemic/\#: \{\}:text=The\%20collective $\% 20 \mathrm{wealth} \% 20 \mathrm{of} \% 20$ all,10\%20months\%20of\%20national\%20emergency (accessed on 8 February 2021).

18. Lauren, B.N.; Silver, E.R.; Faye, A.S.; Rogers, A.M.; Woo Baidal, J.A.; Ozanne, E.M.; Hur, C. Predictors of households at risk for food insecurity in the United States during the COVID-19 pandemic. Public Health Nutr. 2021, 1-19. [CrossRef] [PubMed]

19. Gundersen, C.; Hake, M.; Dewey, A.; Engelhard, E. Food Insecurity during COVID-19. 2021, ePub Ahead of Issue. Appl. Econ. Perspect. Policy 2021, 43, 153-161. [CrossRef]

20. Benfer, E.A.; Vlahov, D.; Long, M.Y.; Walker-Wells, E.; Pottenger, J.L., Jr.; Gonsalves, G.; Keene, D.E. Eviction, Health Inequity, and the Spread of COVID-19: Housing Policy as a Primary Pandemic Mitigation Strategy. J. Urban. Health 2021, 98, 1-12. [CrossRef] [PubMed]

21. The Editors (Anon). Self-Help. Friend 1866, 39, 117-118.

22. Tedeschi, R.G.; Calhoun, L.G. The Posttraumatic Growth Inventory: Measuring the positive legacy of trauma. J. Trauma Stress 1996, 9, 455-471. [CrossRef] [PubMed]

23. Tedeschi, R.G.; Calhoun, L.G. Posttraumatic growth: Conceptual foundations and empirical evidence. Psychol. Inq. 2004, 15, 1-18. [CrossRef]

24. Turner, A.I.; Smyth, N.; Hall, S.J.; Torres, S.J.; Hussein, M.; Jayasinghe, S.U.; Ball, K.; Clow, A.J. Psychological stress reactivity and future health and disease outcomes: A systematic review of prospective evidence. Psychoneuroendocrinology 2020, 114, 104599. [CrossRef] [PubMed]

25. Coimbra, B.M.; Carvalho, C.M.; Ota, V.K.; Vieira-Fonseca, T.; Bugiga, A.; Mello, A.F.; Mello, M.F.; Belangero, S.I. A systematic review on the effects of social discrimination on telomere length. Psychoneuroendocrinology 2020, 120, 104766. [CrossRef]

26. Gavin, A.R.; Woo, B.; Conway, A.; Takeuchi, D. The Association between Racial Discrimination, Posttraumatic Stress Disorder, and Cardiovascular-Related Conditions among Non-Hispanic Blacks: Results from the National Epidemiologic Survey on Alcohol and Related Conditions-III (NESARC-III). J. Racial Ethn Health Disparities 2021. [CrossRef]

27. Bourassa, K.J.; Hendrickson, R.C.; Reger, G.M.; Norr, A.M. Posttraumatic Stress Disorder Treatment Effects on Cardiovascular Physiology: A Systematic Review and Agenda for Future Research. J. Trauma Stress 2020. [CrossRef] [PubMed] 
28. Zieba, M.; Wiechec, K.; Bieganska-Banas, J.; Mieleszczenko-Kowszewicz, W. Coexistence of Post-traumatic Growth and Posttraumatic Depreciation in the Aftermath of Trauma: Qualitative and Quantitative Narrative Analysis. Front. Psychol. 2019, 10, 687. [CrossRef] [PubMed]

29. Triplett, K.N.; Tedeschi, R.G.; Cann, A.; Calhoun, L.G.; Reeve, C.L. Posttraumatic Growth, Meaning in Life, and Life Satisfaction in Response to Trauma. Psychol. Trauma-Us 2012, 4, 400-410. [CrossRef]

30. Mey, L.K.; Chmitorz, A.; Kurth, K.; Wenzel, M.; Kalisch, R.; Tuscher, O.; Kubiak, T. Increases of negative affect following daily hassles are not moderated by neuroticism: An ecological momentary assessment study. Stress Health 2020, 36, 615-628. [CrossRef]

31. Jayawickreme, E.; Infurna, F.J.; Alajak, K.; Blackie, L.E.R.; Chopik, W.J.; Chung, J.M.; Dorfman, A.; Fleeson, W.; Forgeard, M.J.C.; Frazier, P.; et al. Post-traumatic growth as positive personality change: Challenges, opportunities, and recommendations. J. Personal. 2021, 89, 145-165. [CrossRef]

32. Infurna, F.J.; Jayawickreme, E. Fixing the Growth Illusion: New Directions for Research in Resilience and Posttraumatic Growth. Curr. Dir. Psychol. Sci. 2019, 28, 152-158. [CrossRef]

33. Tsai, J.; Pietrzak, R.H. Trajectories of posttraumatic growth among US military veterans: A 4-year nationally representative, prospective cohort study. Acta Psychiatr. Scand. 2017, 136, 483-492. [CrossRef]

34. Tallman, B.; Shaw, K.; Schultz, J.; Altmaier, E. Well-being and posttraumatic growth in unrelated donor marrow transplant survivors: A nine-year longitudinal study. Rehabil. Psychol. 2010, 55, 204-210. [CrossRef]

35. Wolchik, S.A.; Coxe, S.; Tein, J.Y.; Sandler, I.N.; Ayers, T.S. Six-year longitudinal predictors of posttraumatic growth in parentally bereaved adolescents and young adults. Omega (Westport) 2008, 58, 107-128. [CrossRef] [PubMed]

36. Boehm, J.K.; Chen, Y.; Williams, D.R.; Ryff, C.; Kubzansky, L.D. Unequally distributed psychological assets: Are there social disparities in optimism, life satisfaction, and positive affect? PLoS ONE 2015, 10, e0118066. [CrossRef]

37. Zou, R.; Xu, X.; Hong, X.; Yuan, J. Higher Socioeconomic Status Predicts Less Risk of Depression in Adolescence: Serial Mediating Roles of Social Support and Optimism. Front. Psychol. 2020, 11, 1955. [CrossRef]

38. Weyers, S.; Dragano, N.; Mobus, S.; Beck, E.M.; Stang, A.; Mohlenkamp, S.; Jockel, K.H.; Erbel, R.; Siegrist, J. Low socio-economic position is associated with poor social networks and social support: Results from the Heinz Nixdorf Recall Study. Int. J. Equity Health 2008, 7, 13. [CrossRef] [PubMed]

39. Aartsen, M.; Veenstra, M.; Hansen, T. Social pathways to health: On the mediating role of the social network in the relation between socio-economic position and health. SSM Popul. Health 2017, 3, 419-426. [CrossRef]

40. Prescott, S.L.; Logan, A.C. Each meal matters in the exposome: Biological and community considerations in fast-foodsocioeconomic associations. Econ. Hum. Biol. 2017, 27 (Pt B), 328-335. [CrossRef]

41. Hamama-Raz, Y.; Pat-Horenczyk, R.; Roziner, I.; Perry, S.; Stemmer, S.M. Can posttraumatic growth after breast cancer promote positive coping?-A cross-lagged study. Psychooncology 2019, 28, 767-774. [CrossRef] [PubMed]

42. Wu, X.; Kaminga, A.C.; Dai, W.; Deng, J.; Wang, Z.; Pan, X.; Liu, A. The prevalence of moderate-to-high posttraumatic growth: A systematic review and meta-analysis. J. Affect. Disord. 2019, 243, 408-415. [CrossRef]

43. Gilbert, D.T.; Pinel, E.C.; Wilson, T.D.; Blumberg, S.J.; Wheatley, T.P. Immune neglect: A source of durability bias in affective forecasting. J. Personal. Soc. Psychol. 1998, 75, 617-638. [CrossRef]

44. Boals, A.; Bedford, L.A.; Callahan, J.L. Perceptions of Change after a Trauma and Perceived Posttraumatic Growth: A Prospective Examination. Behav. Sci. 2019, 9, 10. [CrossRef]

45. Locke, R. Salk: Be a Good Ancestor; Standard-Speaker: Hazleton, PA, USA, 9 March 1984; p. 10.

46. Walsh, D.M.J.; Groarke, A.M.; Morrison, T.G.; Durkan, G.; Rogers, E.; Sullivan, F.J. Measuring a new facet of post traumatic growth: Development of a scale of physical post traumatic growth in men with prostate cancer. PLoS ONE 2018, 13, e0195992. [CrossRef]

47. Bhushan, B. Perspectives on Posttraumatic Growth. In Psychosocial Interventions for Health and Well-Being; Misra, G., Ed.; Springer: New Delhi, India, 2018. [CrossRef]

48. Zeligman, M.; Varney, M.; Grad, R.I.; Huffstead, M. Posttraumatic Growth in Individuals With Chronic Illness: The Role of Social Support and Meaning Making. J. Couns. Dev. 2018, 96, 53-63. [CrossRef]

49. King, L.A.; Hicks, J.A.; Krull, J.L.; Del Gaiso, A.K. Positive affect and the experience of meaning in life. J. Personal. Soc. Psychol. 2006, 90, 179-196. [CrossRef] [PubMed]

50. Martela, F.; Steger, M.F. The three meanings of meaning in life: Distinguishing coherence, purpose, and significance. J. Posit Psychol. 2016, 11, 531-545. [CrossRef]

51. Burrow, A.L.; Spreng, R.N. Waiting with purpose: A reliable but small association between purpose in life and impulsivity. Personal. Individ. Differ. 2016, 90, 187-189. [CrossRef]

52. Kim, E.S.; Strecher, V.J.; Ryff, C.D. Purpose in life and use of preventive health care services. Proc. Natl. Acad. Sci. USA 2014, 111, 16331-16336. [CrossRef] [PubMed]

53. Kim, E.S.; Shiba, K.; Boehm, J.K.; Kubzansky, L.D. Sense of purpose in life and five health behaviors in older adults. Prev. Med. 2020, 139, 106172. [CrossRef] [PubMed]

54. Zilioli, S.; Slatcher, R.B.; Ong, A.D.; Gruenewald, T.L. Purpose in life predicts allostatic load ten years later. J. Psychosom. Res. 2015, 79, 451-457. [CrossRef] [PubMed]

55. Cohen, R.; Bavishi, C.; Rozanski, A. Purpose in Life and Its Relationship to All-Cause Mortality and Cardiovascular Events: A Meta-Analysis. Psychosom. Med. 2016, 78, 122-133. [CrossRef] [PubMed] 
56. Strecher, V.; Terry, P. Health and life purpose: What's the connection? Am. J. Health Promot. 2014, 29, TAHP2-4. [PubMed]

57. Straus, E.; Norman, S.B.; Tripp, J.C.; Pitts, M.; Pietrzak, R.H. Purpose in Life and Conscientiousness Protect Against the Development of Suicidal Ideation in U.S. Military Veterans with PTSD and MDD: Results from the National Health and Resilience in Veterans Study. Chronic Stress (Thousand Oaks) 2019, 3, 2470547019872172. [CrossRef] [PubMed]

58. Kinoshita, S.; Hirooka, N.; Kusano, T.; Saito, K.; Nakamoto, H. Does Improvement in Health-Related Lifestyle Habits Increase Purpose in Life among a Health Literate Cohort? Int. J. Environ. Res. Public Health 2020, 17, 8878. [CrossRef]

59. Grossmann, I.; Weststrate, N.M.; Ardelt, M.; Brienza, J.P.; Dong, M.X.; Ferrari, M.; Fournier, M.A.; Hu, C.S.; Nusbaum, H.C.; Vervaeke, J. The Science of Wisdom in a Polarized World: Knowns and Unknowns. Psychol. Inq. 2020, 31, 103-133. [CrossRef]

60. Koller, I.; Levenson, M.R.; Gluck, J. What Do You Think You Are Measuring? A Mixed-Methods Procedure for Assessing the Content Validity of Test Items and Theory-Based Scaling. Front. Psychol. 2017, 8, 126. [CrossRef] [PubMed]

61. Yang, S.K.; Ha, Y. Exploring the Relationships between Posttraumatic Growth, Wisdom, and Quality of Life in Older Cancer Survivors. Asian Pac. J. Cancer Prev. 2019, 20, 2667-2672. [CrossRef]

62. Byra, S. Associations between post-traumatic growth and wisdom in people with long-term paraplegia-The role of disability appraisals and participation. Disabil. Rehabil. 2021, 1-8. [CrossRef]

63. Ardelt, M.; Jeste, D.V. Wisdom and Hard Times: The Ameliorating Effect of Wisdom on the Negative Association Between Adverse Life Events and Well-Being. J. Gerontol. B Psychol. Sci. Soc. Sci. 2018, 73, 1374-1383. [CrossRef]

64. Weststrate, N.M.; Gluck, J. Hard-Earned Wisdom: Exploratory Processing of Difficult Life Experience Is Positively Associated With Wisdom. Dev. Psychol. 2017, 53, 800-814. [CrossRef]

65. Plews-Ogan, M.; Ardelt, M.; Owens, J. Growth through Adversity: Exploring Associations between Internal Strengths, Posttraumatic Growth, and Wisdom. J. Value Inquiry 2019, 53, 371-391. [CrossRef]

66. Tedeschi, R.G.; Shakespeare-Finch, J.; Taku, K.; Calhoun, L.G. Posttraumatic growth beyond the individual. In Posttraumatic Growth: Theory, Research, and Applications; Tedeschi, R.G., Ed.; Routledge: New York, NY, USA, 2018.

67. Ferrari, M.; Alhosseini, F. Cultural differences in wisdom. In The Cambridge Handbook of Wisdom; Sternberg, R.J., Gluck, J., Eds.; Cambridge University Press: Cambridge, UK, 2019; pp. 409-428.

68. Yang, S.; Intezari, A. Non-western lay conceptions of wisdom. In The Cambridge Handbook of Wisdom; Sternberg, R.J., Gluck, J., Eds.; Cambridge University Press: Cambridge, UK, 2019; pp. 429-452.

69. Laslo-Roth, R.; George-Levi, S.; Margalit, M. Social participation and posttraumatic growth: The serial mediation of hope, social support, and reappraisal. J. Community Psychol. 2020. [CrossRef]

70. Stallard, P.; Pereira, A.I.; Barros, L. Post-traumatic growth during the COVID-19 pandemic in carers of children in Portugal and the UK: Cross-sectional online survey. BJPsych Open 2021, 7, e37. [CrossRef]

71. Vazquez, C.; Valiente, C.; Garcia, F.E.; Contreras, A.; Peinado, V.; Trucharte, A.; Bentall, R.P. Post-Traumatic Growth and StressRelated Responses during the COVID-19 Pandemic in a National Representative Sample: The Role of Positive Core Beliefs about the World and Others. J. Happiness Stud. 2021, 1-21. [CrossRef]

72. White, R.E.; Kuehn, M.M.; Duckworth, A.L.; Kross, E.; Ayduk, O. Focusing on the future from afar: Self-distancing from future stressors facilitates adaptive coping. Emotion 2019, 19, 903-916. [CrossRef] [PubMed]

73. Grossmann, I.; Kross, E. The impact of culture on adaptive versus maladaptive self-reflection. Psychol. Sci. 2010, 21, 1150-1157. [CrossRef]

74. Dorfman, A.; Oakes, H.; Santos, H.C.; Grossmann, I. Self-distancing promotes positive emotional change after adversity: Evidence from a micro-longitudinal field experiment. J. Personal. 2021, 89, 132-144. [CrossRef]

75. Grossmann, I.; Kross, E. Exploring Solomon's paradox: Self-distancing eliminates the self-other asymmetry in wise reasoning about close relationships in younger and older adults. Psychol. Sci. 2014, 25, 1571-1580. [CrossRef]

76. Kross, E.; Grossmann, I. Boosting wisdom: Distance from the self enhances wise reasoning, attitudes, and behavior. J. Exp. Psychol. Gen. 2012, 141, 43-48. [CrossRef] [PubMed]

77. Huynh, A.C.; Yang, D.Y.J.; Grossmann, I. The Value of Prospective Reasoning for Close Relationships. Soc. Psychol. Personal. Sci. 2016, 7, 893-902. [CrossRef]

78. Glueck, J.; Bluck, S.; Weststrate, N.M. More on the MORE Life Experience Model: What We Have Learned (So Far). J. Value Inquiry 2019, 53, 349-370. [CrossRef]

79. Whitehead, R.; Bates, G.; Elphinstone, B. Growing by Letting Go: Nonattachment and Mindfulness as Qualities of Advanced Psychological Development. J. Adult Dev. 2020, 27, 12-22. [CrossRef]

80. Shiyko, M.P.; Hallinan, S.; Naito, T. Effects of Mindfulness Training on Posttraumatic Growth: A Systematic Review and Meta-Analysis. Mindfulness 2017, 8, 848-858. [CrossRef]

81. Ardelt, M. Can wisdom and psychosocial growth be learned in university courses? J. Moral Educ. 2020, 49, 30-45. [CrossRef]

82. Boulware, J.; Huskey, B.; Mangelsdorf, H.; Nusbaum, H. The Effects of Mindfulness Training on Wisdom in Elementary School Teachers. J. Educ. Soc. Behav. Sci. 2019, 30, 1-10. [CrossRef]

83. Gluck, J. The Important Difference Between Psychologists' Labs and Real Life: Evaluating the Validity of Models of Wisdom. Psychol. Inq. 2020, 31, 144-150. [CrossRef]

84. Stellar, J.E.; Gordon, A.M.; Piff, P.K.; Cordaro, D.; Anderson, C.L.; Bai, Y.; Maruskin, L.A.; Keltner, D. Self-Transcendent Emotions and Their Social Functions: Compassion, Gratitude, and Awe Bind Us to Others Through Prosociality. Emot. Rev. 2017, 9, $200-207$. [CrossRef] 
85. Keltner, D.; Piff, P.K. Self-Transcendent Awe as a Moral Grounding of Wisdom. Psychol. Inq. 2020, 31, 160-163. [CrossRef]

86. Keltner, D.; Haidt, J. Approaching awe, a moral, spiritual, and aesthetic emotion. Cogn. Emot. 2003, 17, 297-314. [CrossRef] [PubMed]

87. Sturm, V.E.; Datta, S.; Roy, A.R.K.; Sible, I.J.; Kosik, E.L.; Veziris, C.R.; Chow, T.E.; Morris, N.A.; Neuhaus, J.; Kramer, J.H.; et al. Big smile, small self: Awe walks promote prosocial positive emotions in older adults. Emotion 2020. [CrossRef]

88. Arcangeli, M.; Sperduti, M.; Jacquot, A.; Piolino, P.; Dokic, J. Awe and the Experience of the Sublime: A Complex Relationship. Front. Psychol. 2020, 11, 1340. [CrossRef] [PubMed]

89. Rudd, M.; Vohs, K.D.; Aaker, J. Awe Expands People's Perception of Time, Alters Decision Making, and Enhances Well-Being. Psychol. Sci. 2012, 23, 1130-1136. [CrossRef] [PubMed]

90. Shiota, M.N.; Keltner, D.; Mossman, A. The nature of awe: Elicitors, appraisals, and effects on self-concept. Cogn. Emot. 2007, 21, 944-963. [CrossRef]

91. Van Cappellen, P.; Saroglou, V. Awe Activates Religious and Spiritual Feelings and Behavioral Intentions. Psychol. Relig. Spirit. 2012, 4, 223-236. [CrossRef]

92. Stellar, J.E.; John-Henderson, N.; Anderson, C.L.; Gordon, A.M.; McNeil, G.D.; Keltner, D. Positive Affect and Markers of Inflammation: Discrete Positive Emotions Predict Lower Levels of Inflammatory Cytokines. Emotion 2015, 15, 129-133. [CrossRef] [PubMed]

93. Schneider, K.J. Awe: More than a lab experience-A rejoinder to "awe: 'more than a feeling'" by Alice Chirico and Andrea Gaggioli. Humanist. Psychol. 2020, 48, 100-104. [CrossRef]

94. Schneider, K.J. The Depolarizing of America. A Guidebook for Social Healing; University Professors Press: Colorado Springs, CO, USA, 2020.

95. Sun, X.; Su, W.; Guo, X.; Tian, Z. The Impact of Awe Induced by COVID-19 Pandemic on Green Consumption Behavior in China. Int. J. Environ. Res. Public Health 2021, 18, 543. [CrossRef]

96. Frankl, V. Man's Search for Meaning; Beacon Press: Boston, MA, USA, 1959.

97. Koliouli, F.; Canellopoulos, L. Dispositional Optimism, Stress, Post-traumatic stress Disorder and Post-traumatic Growth in Greek general population facing the COVID-19 crisis. Eur. J. Trauma Dissociation 2021, 100209. [CrossRef]

98. Malouff, J.M.; Schutte, N.S. Can psychological interventions increase optimism? A meta-analysis. J. Posit Psychol. 2017, 12, 594-604. [CrossRef]

99. Scheier, M.F.; Swanson, J.D.; Barlow, M.A.; Greenhouse, J.B.; Wrosch, C.; Tindle, H.A. Optimism versus pessimism as predictors of physical health: A comprehensive reanalysis of dispositional optimism research. Am. Psychol. 2020. [CrossRef]

100. Heinonen, K.; Raikkonen, K.; Matthews, K.A.; Scheier, M.F.; Raitakari, O.T.; Pulkki, L.; Keltikangas-Jarvinen, L. Socioeconomic status in childhood and adulthood: Associations with dispositional optimism and pessimism over a 21-year follow-up. J. Personal. 2006, 74, 1111-1126. [CrossRef]

101. Robb, K.A.; Simon, A.E.; Wardle, J. Socioeconomic disparities in optimism and pessimism. Int. J. Behav. Med. 2009, 16, 331-338. [CrossRef]

102. Chipperfield, J.G.; Hamm, J.M.; Perry, R.P.; Parker, P.C.; Ruthig, J.C.; Lang, F.R. A healthy dose of realism: The role of optimistic and pessimistic expectations when facing a downward spiral in health. Soc. Sci. Med. 2019, 232, 444-452. [CrossRef]

103. Alkalay, S.; Sagi-Schwartz, A.; Wiseman, H. Increased empathy and helping behavior toward the mother in daughters of Holocaust survivors. Traumatology 2020, 26, 84-95. [CrossRef]

104. Zwahlen, D.; Hagenbuch, N.; Carley, M.I.; Jenewein, J.; Buchi, S. Posttraumatic growth in cancer patients and partners-effects of role, gender and the dyad on couples' posttraumatic growth experience. Psychooncology 2010, 19, 12-20. [CrossRef] [PubMed]

105. Manne, S.; Ostroff, J.; Winkel, G.; Goldstein, L.; Fox, K.; Grana, G. Posttraumatic growth after breast cancer: Patient, partner, and couple perspectives. Psychosom. Med. 2004, 66, 442-454.

106. Cormio, C.; Romito, F.; Viscanti, G.; Turaccio, M.; Lorusso, V.; Mattioli, V. Psychological well-being and posttraumatic growth in caregivers of cancer patients. Front. Psychol. 2014, 5, 1342. [CrossRef] [PubMed]

107. Kamibeppu, K.; Sato, I.; Honda, M.; Ozono, S.; Sakamoto, N.; Iwai, T.; Okamura, J.; Asami, K.; Maeda, N.; Inada, H.; et al. Mental health among young adult survivors of childhood cancer and their siblings including posttraumatic growth. J. Cancer Surviv. 2010, 4, 303-312. [CrossRef]

108. Greene, T.; Lahav, Y.; Kanat-Maymon, Y.; Solomon, Z. A Longitudinal Study of Secondary Posttraumatic Growth in Wives of Ex-POWs. Psychiatry 2015, 78, 186-197. [PubMed]

109. Dar, I.A.; Iqbal, N. Beyond linear evidence: The curvilinear relationship between secondary traumatic stress and vicarious posttraumatic growth among healthcare professionals. Stress Health 2020, 36, 203-212. [CrossRef]

110. Doherty, M.E.; Scannell-Desch, E.; Bready, J. A Positive Side of Deployment: Vicarious Posttraumatic Growth in U.S. Military Nurses Who Served in the Iraq and Afghanistan Wars. J. Nurs. Scholarsh. 2020, 52, 233-241. [CrossRef]

111. Zerach, G. "He ain't heavy, he's my brother": Distress tolerance moderates the association between secondary posttraumatic symptoms and secondary posttraumatic growth among siblings of combat veterans. Psychol. Trauma 2020, 12, 687-697. [CrossRef] [PubMed]

112. Maitlis, S. Posttraumatic Growth at Work. Annu Rev. Organ. Psych. 2020, 7, 395-419. [CrossRef]

113. Olson, K.; Shanafelt, T.; Southwick, S. Pandemic-Driven Posttraumatic Growth for Organizations and Individuals. JAMA 2020, 324, 1829-1830. [CrossRef] 
114. Hormann, S.; Vivian, P. Organizational trauma in university settings. In Emerging Contours of Excellence; Mohan, J., Ed.; Punjab University of Press: Chandigarh, India, 2017; pp. 188-198.

115. Alexander, B.N.; Greenbaum, B.; Shani, A.B.; Mitki, Y. Organizational Post-Traumatic Growth: Thriving After Adversity. Acad. Manag. Proc. 2020, 2020, 18506. [CrossRef]

116. Calhoun, L.G.; Tedeschi, R.G. Posttraumatic Growth in Clinical Practice; Routledge: East Sussex, UK, 2013.

117. Vázquez, C.; Pérez-Sales, P.; Hervás, G. Positive effects of terrorism and posttraumatic growth: An individual and community perspective. In Trauma, Recovery, and Growth: Positive Psychological Perspectives on Posttraumatic Stress; Joseph, S., Linley, P.A., Eds.; John Wiley \& Sons Inc.: Hoboken, NJ, USA, 2008; pp. 63-91.

118. Eaton-Robb, P. Sandy Hook: Families Dedicate Time to Charity, Activism 5 Years after Tragedy; Associated Press, 14 December 2017; Available online: https:/ / www.usatoday.com/story/news/nation/2017/12/13/sandy-hook-school-shooting-families-5-yearanniversary /951016001/ (accessed on 5 March 2021).

119. Wilcox, A.M. "We've Had Enough": Youth Activists' Pathways to Participation and Social Media Practices Following the Parkland Shooting. Clemson University, All Dissertations. 2020, p. 2698. Available online: https://tigerprints.clemson.edu/all_ dissertations / 2698 (accessed on 5 March 2021).

120. Kirby, T. Evidence mounts on the disproportionate effect of COVID-19 on ethnic minorities. Lancet Respir. Med. 2020, 8, 547-548. [CrossRef]

121. Barber, R.; Law, S.F. Exposing Inequity in Australian Society: Are we all in it Together? Soc. Health Sci. 2020, 18, 96-115.

122. Pauls, J.E. The Impact of Posttraumatic Growth on Authentic Leader Development: Five Portraits of Women Cancer Survivors in Leadership. Gonzaga University, ProQuest Dissertations Publishing. Number 10666061. 2017. Available online: https: / / search.proquest.com/openview /0a8862b27dba3b281b0f97e32ef32cc1/1?cbl=18750\&diss=y\&pq-origsite=gscholar (accessed on 12 February 2021).

123. Gluck, J. Wisdom vs. populism and polarization: Learning to regulate our evolved intuitions. In Applying Wisdom to Contemporary World Problems; Sternberg, R.J., Ed.; Palgrave MacMillan: London, UK, 2019.

124. Griskevicius, V.; Cantu, S.M.; van Vugt, M. The Evolutionary Bases for Sustainable Behavior: Implications for Marketing, Policy, and Social Entrepreneurship. J. Public Policy Mark. 2012, 31, 115-128. [CrossRef]

125. Mischinski, M.; Jayawickreme, E. Can moral exemplars promote wisdom. In Applying Wisdom to Contemporary World Problems; Sternberg, R.J., Ed.; Palgrave MacMillan: London, UK, 2019.

126. Dickinson, S. Post-traumatic growth in the twenty-first century: How current trends may threaten our ability to grow after trauma. J. Posit. Psychol. 2020. [CrossRef]

127. Prescott, S.L.; Bland, J.S. Spaceship Earth Revisited: The Co-Benefits of Overcoming Biological Extinction of Experience at the Level of Person, Place and Planet. Int. J. Environ. Res. Public Health 2020, 17, 1407. [CrossRef]

128. Seligman, M.; Flourish, A. Visionary New Understanding of Happiness and Well-Being; Free Press: New York, NY, USA, 2011. 